\title{
The public as a problem: protest, public diplomacy and the pandemic
}

\author{
César Jiménez-Martínez ${ }^{1}$ D
}

Revised: 13 September 2021 / Accepted: 20 September 2021 / Published online: 26 October 2021

(c) The Author(s), under exclusive licence to Springer Nature Limited 2021

\begin{abstract}
With the coronavirus pandemic deepening pre-existing social issues, protests have re-emerged around the world. It is, however, noteworthy that debates in public diplomacy and place branding have remained largely silent about these episodes. This contribution argues that protests should be taken into account within the field. They not only stress the contested nature of nationhood, but crucially, they also shed light on the troubled relationship that practitioners and scholars have with the 'public', which is usually approached as a mere problem or a resource to be exploited in order to benefit those in power.
\end{abstract}

Keywords Protests $\cdot$ Covid-19 $\cdot$ Nationhood $\cdot$ Public Diplomacy $\cdot$ Place Branding

\section{Introduction}

One of the many questions raised in March 2020, when most of the world went into lockdown due to the Covid19 pandemic, referred to the immediate future of protests. The previous year had been particularly productive for social movements, with massive demonstrations around the globe and millions of people targeting corruption, bad governance, state violence and social inequality, among other issues (Pleyers 2020). In the Southern Hemisphere in particular, the end of summer prompted activists to forecast that protests were going to resume with new impetus in March 2020 (Rincón 2020). Yet, the increasing number of extraordinary restrictions introduced by governments, as well as the greater reliance on authorities' guidance during an unprecedented global health crisis, put an abrupt halt to most expressions of social dissent.

The pandemic, however, deepened pre-existing social issues. Structural gender, class and racial inequalities were exposed further when income sources shrunk, healthcare access was reduced and lives were lost (Kowalewski 2020;

I would like to express gratitude to my colleague Alina Dolea, who has generously allowed me to share some ideas that we have discussed about the understudied relationship between protests, public diplomacy and soft power. We are currently developing these ideas together into a longer article.

César Jiménez-Martínez

JimenezMartinezC@ cardiff.ac.uk

1 Cardiff University, 2 Central Square, Cardiff CF10 1FS, UK
Calvente 2021). Consequently, it did not take long for protests to re-emerge, sometimes in direct defiance of newly introduced restrictions. Since mid-2020, places such as Australia, Chile, Colombia, Greece, Lebanon, France, the United Kingdom and particularly the United States, among many others, have been shaken by dramatic scenes of hundreds and sometimes thousands taking to the streets, driven by a whole array of often contradictory grievances, including calls to expand the welfare state, resist a takeover of personal freedoms, oppose vaccination programmes and the use of masks, denounce racism and police brutality, undermine the Black Lives Matter movement, and even storm the American Capitol to overthrow a legitimate presidential election (Pleyers 2020; Bratich 2021).

In line with previous trends (see Cottle and Lester 2011; Gerbaudo 2017; Cammaerts 2018), these various demonstrations have had both a domestic and transnational character. Protesters have predominantly targeted national governments rather than global corporations or transnational organisations; they have relied on social media while also trying to get favourable coverage by local news organisations; and crucially, they have justified grievances by claiming to act on behalf of the nation. Their actions have nonetheless been witnessed by —and staged for-overseas audiences, particularly international news organisations. Protest news coverage has therefore become a substantial part of the collage of 'cumulative pictures of the social totality' that make a nation visible (Frosh and Wolfsfeld 2007, p. 126).

This visibility of dissent is particularly relevant when taking into account that, despite its obvious global nature, 
the pandemic has predominantly been framed as a national endeavour. Government responses have largely been driven by competition rather than collaboration and cross-national solidarity, as evidenced by blame games between states, the imposition of border closures, local pride at containing the virus more effectively than others and increasing 'vaccine nationalism' (Wang 2021; Kloet et al. 2020). Public expressions of dissent and domestic conflict, and the authorities' response to them, have consequently become another tool in the evaluation of how 'well' or 'badly' a nation-state is doing in the eyes of the world.

It is, however, noteworthy that debates in public diplomacy, place branding and strategic communications have had very little to say about these episodes. This was also true before the pandemic. At most, when protests are covered by overseas news organisations, diplomats, politicians and communication strategists interpret them as potentially damaging to the image or reputation of a nation, as previous events in Brazil, Hong Kong and Chile demonstrate (Jiménez-Martínez 2020; Loh 2017). Moreover, scholars in the field have only marginally addressed dissent and disruption (Pamment 2021). When they do discuss social movements and demonstrations, they frame them as threats (Loh 2017), part of the environment where states operate (Melissen 2005), expressions of a stronger civil society appealing for support of Western public opinion (Zhang and Fahmy 2015), or manifestations of the so-called 'citizen diplomacy' (Huijgh 2019).

This is a significant shortcoming. Public diplomacy, place branding and other 'soft power' practices are justified as a means to communicate the 'essence' of a nation (Aronczyk 2013). This approach, however, assumes that identities are stable and fixed and that, crucially, states can successfully identify and mobilise them for political or economic purposes. It consequently glosses over the shifting and contested nature of nationhood, with various actors creating and communicating competing versions of what a nation 'actually' is (Mihelj 2011). Protests are a key component of these struggles, with individuals and organisations outside the state rejecting and subverting state narratives and images, and making visible alternative arrangements of what the national community should stand for, as well as demanding the expansion or contraction of political, economic and symbolic boundaries determining who belongs and who does not belong to a nation, along with the conditions for such belonging (Jiménez-Martínez 2020).

It therefore does not suffice, as politicians, diplomats and communication consultants often claim (see Aronczyk 2013), to aim to simply communicate the 'authentic' national identity at times of conflict or social unrest. The existence of such identity is not only debatable, but worse, it can be used as a justification to undermine democracy and prevent structural change through fantasies of moral and national superiority. For instance, at the beginning of the 2019 outbreak of social unrest in Chile, President Sebastián Piñera claimed that the nation was 'at war against a powerful enemy' (Somma 2021), thus drawing a boundary between 'us', the allegedly good law-abiding citizens, vis-àvis 'them', the 'thugs' or 'vandals' expressing their discontent. Likewise, the structural racism and police brutality that drove thousands on to the streets in the United States during 2020 were often underplayed as 'non-American' (Olson 2021), while those taking a knee as a gesture against racism were labelled as 'unpatriotic' by right-wing politicians and media pundits.

Following Appadurai (1990), the Covid-19 pandemic has deepened the disjuncture between the nation and the state. People all over the world have taken to both social media and the streets to express their discontent and directly challenge authorities, in order to demand better healthcare and social protection, as well as to denounce the exploitative monopoly that states claim to have over violence and over the symbolic representation of a nation. Yet, public diplomacy and place branding scholars have remained largely silent about these processes. This is partly due to their fixation on the state as the main actor behind the overseas communication of the nation, therefore becoming oblivious to the fact that the nation-state and the nation-people may sometimes conflict with each other. When this happens, the mirage underpinning attempts to communicate the 'real' version of a nation vanishes. What is more authentic? The glossy and harmonious promotional narratives manufactured by state propaganda or the angrier, rawer, more spontaneous and often contradictory expressions by ordinary citizens?

Expressions of dissent therefore point to at least two important limitations of the practice and understanding of public diplomacy and place branding. First, top-down attempts to impose a particular version of national identity, especially those seeking to achieve political and economic goals, have been increasingly undermined by a cacophony of voices 'from below' that, with the assistance of digital technologies, claims to stand for the 'authentic' nation (Mihelj and Jiménez-Martínez 2021). Consequently, versions of national identity produced by authorities or communication consultants are only one among several competing and often contradictory accounts of what a nation supposedly is (Kaufmann 2017; Pamment 2021).

Second, episodes of protest shed light on the problematic relationship that the practice and theory of public diplomacy actually have with individuals and organisations outside the state. Despite claims of listening to or engaging with the public, diplomats, politicians and communication strategists have historically considered the people either as a problem-particularly during the conduct of negotiations or in situations of conflict—or as a resource to be exploited in order to benefit those in power 
(La Cour 2018). Hence, when protests happen to 'us', they are interpreted as missed opportunities to project a positive image overseas or as unrepresentative deviances of who 'we' really are (Jiménez-Martínez 2020; Loh 2017). Conversely, when they happen elsewhere, they are praised as evidence of the public exposing the 'real' nation concealed by official propaganda efforts, or as emerging signs of democracy and 'universal'-namely Western-values (Zhang and Fahmy 2015).

The Covid-19 pandemic has not only dramatically disrupted contemporary life, but it has also strengthened the significance of nations as key articulators of individual and collective identities (Kloet et al. 2020; Wang 2021). Although there is potential for a new era of transnational protest due to the similarity of grievances across societies, the various demonstrations that have erupted so far have predominantly disputed the content rather than the form of the nation-they have not put forward alternative local, regional or global forms of social organisation. Yet, as episodes of dissent around the world demonstrate, the national form is a site of continuous struggle, with individuals and organisations inside and outside the state justifying the quest and maintenance of power by claiming to act on behalf of the nation. Public diplomacy and place branding practitioners and scholars should therefore abandon the fantasy that a perennial national 'essence' can be communicated. Instead, they should acknowledge that other social actors, beyond the institutions of the state, may be equally valid representatives of the nation, and that chaos, conflict and transformation are at the core of nationhood, rather than chimaeras of homogeneity, stability and authenticity. Moreover, they should also recognise that the very basis of their practice, that is, the construction and dissemination of state-sanctioned versions of national identity, can be targeted by groups that consider it an exploitative project, aimed to benefit those in power at the expense of the members of a given human community.

\section{Declarations}

Conflict of interest César Jiménez-Martínez states that there is no conflict of interest.

\section{References}

Appadurai, Arjun. 1990. Disjuncture and Difference in the Global Cultural Economy. Theory, Culture \& Society 7: 295-310. https://doi.org/10.1215/08992363-2-2-1.

Aronczyk, Melissa. 2013. Branding the Nation: The Global Business of National Identity. Oxford: Oxford University Press.

Bratich, Jack. 2021. 'Give Me Liberty or Give Me Covid!': Anti-Lockdown Protests as Necropopulist Downsurgency. Cultural Studies 35 (2-3): 257-265. https://doi.org/10.1080/09502386.2021.1898016.
Calvente, Lisa. 2021. Racism Is a Public Health Crisis! Black Power in the COVID-19 Pandemic. Cultural Studies 35 (2-3): 266278. https://doi.org/10.1080/09502386.2021.1898017.

Cammaerts, Bart. 2018. The Circulation of Anti-austerity Protest. Basingstoke: Palgrave Macmillan.

Cottle, Simon, and Libby Lester. 2011. Transnational Protests and the Media: An Introduction. In Transnational Protests and the Media, ed. Simon Cottle and Libby Lester, 3-16. New York: Peter Lang.

de Kloet, Jeroen, Jian Lin, and Yiu Fai Chow. 2020. 'We Are Doing Better': Biopolitical Nationalism and the COVID-19 Virus in East Asia. European Journal of Cultural Studies. https://doi. org/10.1177/1367549420928092.

Frosh, Paul, and Gadi Wolfsfeld. 2007. ImagiNation: News Discourse, Nationhood and Civil Society. Media, Culture \& Society 29 (1): 105-129. https://doi.org/10.1177/0163443706072001.

Gerbaudo, Paolo. 2017. The Mask and the Flag: Populism, Citizenism and Global Protest. London: Hurst \& Company.

Huijgh, Ellen. 2019. Public Diplomacy at Home: Domestic Dimensions. Leiden: Brill Nijhoff University Press.

Jiménez-Martínez, César. 2020. Media and the Image of the Nation during Brazil's 2013 Protests. Cham: Palgrave Macmillan.

Kaufmann, Eric. 2017. Complexity and Nationalism. Nations and Nationalism 23 (1): 6-25. https://doi.org/10.1111/nana.12270.

Kowalewski, Maciej. 2020. Street Protests in Times of COVID-19: Adjusting Tactics and Marching 'as Usual.' Social Movement Studies. https://doi.org/10.1080/14742837.2020.1843014.

La Cour, Christina. 2018. The Evolution of the 'public' in Diplomacy. Place Branding and Public Diplomacy 14 (1): 22-35. https://doi.org/10.1057/s41254-017-0093-3.

Loh, Dylan. 2017. Defending China's National Image and 'Defensive Soft Power': The Case of Hong Kong's 'Umbrella Revolution.' Journal of Chinese Political Science 22 (1): 117-134. https:// doi.org/10.1007/s11366-016-9419-x.

Melissen, Jan. 2005. The New Public Diplomacy: Soft Power in International Relations. Studies in Diplomacy and International Relations. London: Palgrave Macmillan.

Mihelj, Sabina. 2011. Media Nations: Communicating Belonging and Exclusion in the Modern World. New York: Palgrave Macmillan.

Mihelj, Sabina, and César. Jiménez-Martínez. 2021. Digital Nationalism: Understanding the Role of Digital Media in the Rise of 'New' Nationalism. Nations and Nationalism 27 (2): 331-346. https://doi.org/10.1111/nana.12685.

Olson, Christa J. 2021. Introduction: This Is America. Journal for the History of Rhetoric 24 (1): 1-6. https://doi.org/10.1080/ 26878003.2021.1881306.

Pamment, James. 2021. Does Public Diplomacy Need a Theory of Disruption? The Role of Nonstate Actors in Counter-Branding the Swedish COVID-19 Response. Journal of Public Diplomacy 1 (1): 80-110. https://doi.org/10.23045/jpd.2021.1.1.080.

Pleyers, Geoffrey. 2020. The Pandemic Is a Battlefield. Social Movements in the COVID-19 Lockdown. Journal of Civil Society 16 (4): 295-312. https://doi.org/10.1080/17448689.2020.1794398.

Rincón, Andrea. 2020. "Las Protestas Resurgen En Chile Con El Regreso de Los Estudiantes a Las Calles Tras El Verano." France24, March 7, 2020. https://www.france24.com/es/20200 307-chile-protestas-pi\%C3\%B1era-pinochet-constituci\%C3\%B3n.

Somma, Nicolás M. 2021. Power Cages and the October 2019 Uprising in Chile. Social Identities. https://doi.org/10.1080/13504 630.2021 .1931092$.

Wang, Zhongyuan. 2021. From Crisis to Nationalism?: The Conditioned Effects of the COVID-19 Crisis on Neo-Nationalism in Europe. Chinese Political Science Review 6 (1): 20-39. https:// doi.org/10.1007/s41111-020-00169-8.

Zhang, J., and S. Fahmy. 2015. Live Tweeting At Work: The Use of Social Media in Public Diplomacy. In International Public Relations and Public Diplomacy: Communication and 
Engagement, ed. Guy J. Golan, Sung-Un. Yang, and Dennis Kinsey, 315-330. New York: Peter Lang.

Publisher's Note Springer Nature remains neutral with regard to jurisdictional claims in published maps and institutional affiliations.
César Jiménez-Martínez is a Lecturer in Global Media and Communications at Cardiff University. His research focuses on mediated nationhood, protest, visibility, journalism, nation branding and public diplomacy. He is the author of the monograph Media and the Image of the Nation during Brazil's 2013 Protests (2020, Palgrave Macmillan). 